\title{
Extremely high white blood cell counts on postoperative day 1 do not predict severe complications following distal pancreatectomy
}

\author{
Gun Hee Jung ${ }^{1}$, Ho Kyoung Hwang ${ }^{1,2,3}$, Woo Jung Lee ${ }^{1,2,3}$, and Chang Moo Kang ${ }^{1,2,3}$ \\ ${ }^{1}$ Department of Surgery, Yonsei University College of Medicine, ${ }^{2}$ Division of Hepatobiliary and Pancreatic Surgery, \\ Department of Surgery, Yonsei University College of Medicine, ${ }^{3}$ Pancreatobiliary Cancer Clinic, \\ Yonsei Cancer Center, Severance Hospital, Seoul, Korea
}

\begin{abstract}
Backgrounds/Aims: Distal pancreatectomy(DP) is associated with high morbidity. In clinical practice, postoperative white blood cell(WBC) counts are useful indicators of infection complications. The aim of this study was to determine the relevance of extremely high postoperative day (POD)1 WBC counts after DP and their relationship to perioperative outcomes. Methods: From December 2005 to December 2016, data from patients who had open or minimally invasive DP surgery (robot or laparoscopy, MIS) for benign or borderline malignant tumors were retrospectively reviewed. Patients were divided into groups based on POD1 WBC count ( $>20 \mathrm{~K}$, High and $<20 \mathrm{~K}$, Low) for comparisons. Results: Twelve patients $(4.6 \%)$ were categorized into the High group. There were significant differences in age $(p=0.019)$, BMI $(p=0.010)$, and spleen-preserving rate $(p=0.002)$ between the High and Low groups. In binary logistic regression analysis, the risk factors for severe complication was age $(p=0.032)$ and open DP $(p=0.005)$, not POD1 WBC count. Conclusions: Extremely high WBC count after POD1 after DP was not associated with severe complications, but was associated with splenectomy. Surgical methods and age were associated with severe complications. (Ann Hepatobiliary Pancreat Surg 2019;23:377-384)
\end{abstract}

Key Words: WBC; Distal pancreatectomy; Minimally invasive surgery; Leukocytosis; Postoperative pancreatic fistula; Retrospective study

\section{INTRODUCTION}

Mortality rates in pancreatic surgery have declined markedly throughout the last decade due to the advancement of surgical methods and imaging techniques; ${ }^{1-3}$ however, morbidity rates remain high for distal pancreatectomy (DP). ${ }^{4,5}$ The most life-threatening complication of DP is a postoperative pancreatic fistula (POPF). The incidence of POPF after DP has been reported to range from 18.6 to $64.9 \%{ }^{6,7}$ POPF causes a variety of complications, such as intra-abdominal abscess, delayted gastric emptying, and postoperative hemorrhage. Therefore, early diagnosis and treatment of POPF are of vital importance.

Leukocytosis is frequently found in the early postoperative period after major surgery. Although leukocytosis may be a sign of developing infection in the early postoperative period, it may also be part of a normal surgical response. Systemic inflammatory response syndrome (SIRS) is considered a useful parameter for early detection of postoperative complications and end-organ dysfunction after gastrointestinal surgery. ${ }^{8}$ One of the diagnostic criteria for SIRS is a white blood cell (WBC) count $>12 \mathrm{k}$ cells $/ \mu \mathrm{l}$ or $<4 \mathrm{k}$ cells $/ \mu \mathrm{l}$. Thus, it is reasonable to infer that a higher WBC count in the post-operative blood test after DP indicates a worse prognosis.

Interestingly, in clinical practice, it is uncommon to find a WBC count $>20 \mathrm{k}$ cells $/ \mu \mathrm{l}$ on postoperative day 1 (POD1) following DP, raising questions about the use of this parameter as a predictor of complication following DP. Therefore, in this study, we investigated whether a WBC count $>20 \mathrm{k}$ cells $/ \mu 1$ on POD1 influences the postoperative course following DP for benign and low-grade

Received: June 19, 2019; Revised: July 14, 2019; Accepted: July 25, 2019

Corresponding author: Chang Moo Kang

Division of Hepatobiliary and Pancreatic Surgery, Department of Surgery, Yonsei University College of Medicine, 50 Yonsei-ro, Seodaemun-gu, Seoul 03722, Korea

Tel: +82-2-2228-2100-3, Fax: +82-2-313-8289, E-mail: cmkang@yuhs.ac

Copyright (C) 2019 by The Korean Association of Hepato-Biliary-Pancreatic Surgery

This is an Open Access article distributed under the terms of the Creative Commons Attribution Non-Commercial License (http://creativecommons.org/ icenses/by-nc/4.0) which permits unrestricted non-commercial use, distribution, and reproduction in any medium, provided the original work is properly cited. Annals of Hepato-Biliary-Pancreatic Surgery - pISSN: 2508-5778 - elSSN: 2508-5859 
malignant tumors of the left-side of the pancreas.

\section{MATERIALS AND METHODS}

\section{Study design}

The Yonsei Institutional Review Board approved the current study protocol (4-2018-1114). The medical records of 474 patients who underwent DP from December 2005 to December 2016 were retrospectively reviewed using the Electronic Medical Record Database. Among them, patients with malignant pancreatic tumors $(n=179)$ and DP secondary to primary cancer surgery $(n=35)$ were excluded (Fig. 1). Patients were categorized into two groups according to their WBC count on POD1: $>20 \mathrm{k}$ cells $/ \mu \mathrm{l}$ (Group 20K-High) or $<20 \mathrm{k}$ cells/ $\mu$ (Group 20K-Low). Perioperative outcomes were compared according to WBC count on POD1.

\section{Data collection}

Perioperative variables, including age, gender, body mass index (BMI), length of hospital (LOH) stay, operative time, estimated blood loss (EBL), intraoperative transfusion (Yes/No, ml), reoperation, readmission, and surgical approach (distal pancreatectomy with splenectomy [DPS] vs. spleen-preserving distal pancreatectomy [SPDP]), were retrospectively determined. Additionally, the WBC counts on preoperative day, operation (OP) day, POD1, POD2, POD3, POD5, POD7, and day 1 of out-patient department (OPD) follow-up were collected. Complications were classified according to the Clavien-Dindo classification system. ${ }^{9}$ POPF was defined by the amylase level in the drainage fluid on POD3 based on the (Internal Study Group of Pancreatic Fistula (ISGPF) guidelines. ${ }^{10}$

\section{Statistical analysis}

Continuous variables were described as mean \pm standard deviation, and categorical variables were described as frequency (\%). Student's t-test, Chi-square test with Fisher's exact test, and linear-by-linear association were performed using SPSS 20.0 for Windows (SPSS Inc., Chicago, IL, USA). The resultant $p$-values $<0.05$ were considered to be statistically significant.

\section{RESULTS}

\section{Patient characteristics}

Of the 260 intention-to-treat patients, 164 (63\%) were female. The average patient age was $51.75 \pm 15.2 \mathrm{y}$. The preoperative mean BMI was $23.09 \pm 3.2 \mathrm{~kg} / \mathrm{m}^{2}$. Intraductal papillary mucinous neoplasm (IPMN) of the pancreas was the most common pathologic condition (18.8\%), and solid pseudopapillary neoplasm (SPN) was the second most common (16.2\%; Table 1).

Among the study population, $84(32.3 \%)$ patients underwent open surgery, while the remaining $176(67.6 \%)$ patients underwent minimally invasive surgery (MIS). It

Table 1. Histological analysis of 260 distal pancreatectomy cases

$$
\text { Histological diagnosis } \quad \text { N (\%) }
$$

Intraductal papillary mucinous neoplasm (IPMN) 49 (18.8) Solid pseudopapillary neoplasm (SPN) $\quad 42$ (16.2) Neuroendocrine tumor (NET) 41 (15.8) Mucinous cystadenoma (MCN) 30 (11.5) Serous cystadenoma $21(8.1)$ Pseudocyst 11 (4.2) Others 66 (25.4)

Total 260

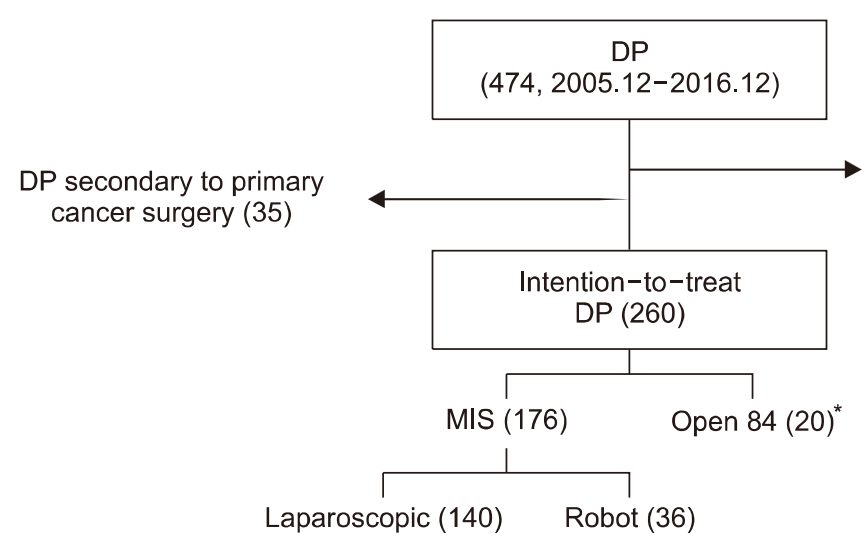

Malignant pancreatic tumor (179) 


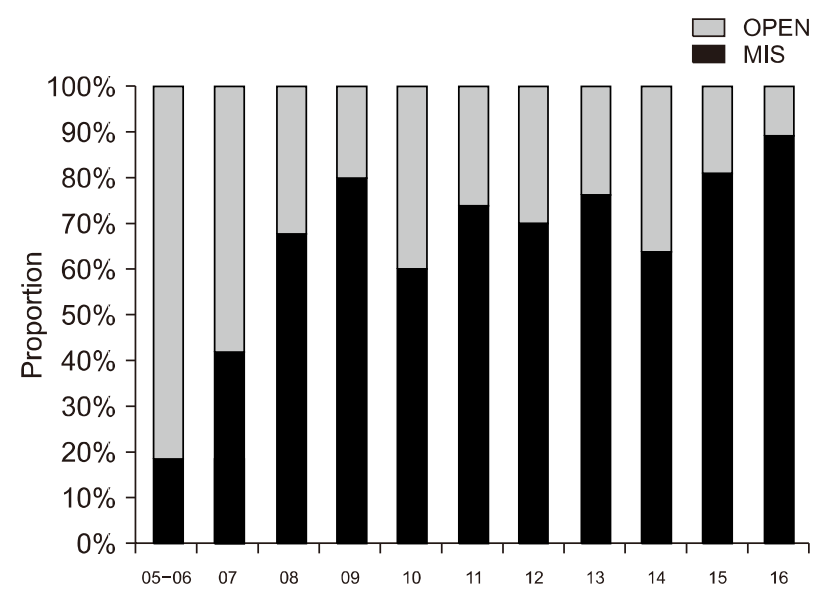

Fig. 2. Proportion of MIS for DP at Yonsei University Health System, Seoul, Korea. There was increasing trend annually $(p<0.001)$ for MIS. MIS, minimally invasive surgery; DP, distal pancreatectomy.

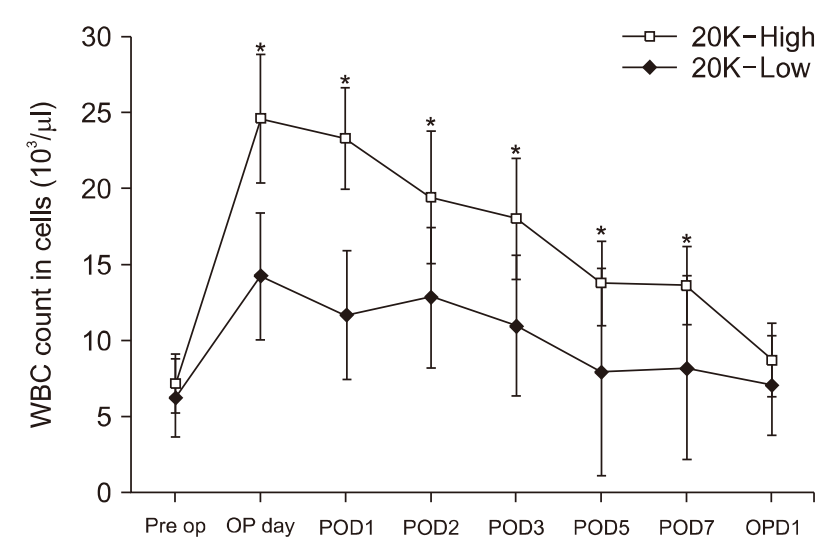

Fig. 3. WBC count profiles preoperative, POD1-7 and at the first OPD follow-up. Data is shown as number (\%) or mean \pm SD. WBC, white blood cell; POD, postoperative day; OPD, out-patient department. $*<0.05$.

Table 2. Univariable associations between Group 20K-High, Group 20K-Low, and baseline characteristics

\begin{tabular}{|c|c|c|c|}
\hline Variable & Group 20K-High $(\mathrm{N}=12)$ & Group 20K-Low $(\mathrm{N}=248)$ & $p$-value \\
\hline Age, y, mean (SD) & $41.92 \pm 17.0$ & $52.22 \pm 15.0$ & $0.019^{*}$ \\
\hline $\mathrm{BMI}, \mathrm{kg} / \mathrm{m}^{2}(\mathrm{SD})$ & $20.48 \pm 4.1$ & $23.22 \pm 3.1$ & $0.010^{*}$ \\
\hline Gender, n (\%) & & & 0.120 \\
\hline Male & $7(58.3)$ & $89(35.9)$ & \\
\hline Female & $5(41.7)$ & $159(64.1)$ & \\
\hline Operative time, $\min (\mathrm{SD})$ & $258.33 \pm 89.6$ & $234.26 \pm 91.0$ & 0.384 \\
\hline Surgical approach, n (\%) & & & 0.187 \\
\hline MIS & $6(50.0)$ & $170(68.5)$ & \\
\hline Open & $6(50.0)$ & $78(31.5)$ & \\
\hline Spleen preserving, n (\%) & & & $0.002 *$ \\
\hline Yes & $0(0)$ & $114(46)$ & \\
\hline No & $12(100)$ & $134(54)$ & \\
\hline EBL & $350.00 \pm 406.76$ & $260.04 \pm 328.65$ & 0.361 \\
\hline Transfusion $(\mathrm{ml})$ & $64.17 \pm 160.54$ & $29.48 \pm 124.44$ & 0.353 \\
\hline Transfusion, $\mathrm{n}(\%)$ & & & 0.232 \\
\hline Yes & $2(16.7)$ & $18(7.3)$ & \\
\hline No & $10(83.3)$ & $230(92.7)$ & \\
\hline Complication, n (\%) & & & 0.067 \\
\hline Yes & $7(58.3)$ & $79(31.9)$ & \\
\hline No & $5(41.7)$ & $169(68.1)$ & \\
\hline Complication, n (\%) & & & 0.877 \\
\hline No, CD-I, II & $11(91.7)$ & $224(90.3)$ & \\
\hline CD-III, IV & $1(8.3)$ & $24(9.7)$ & \\
\hline POPF, n (\%) & & & 0.755 \\
\hline No & $8(66.7)$ & $160(64.5)$ & \\
\hline Grade A & $4(33.3)$ & $81(32.7)$ & \\
\hline Grade $B+C$ & $0(0)$ & $7(2.8)$ & \\
\hline Length of hospital stay (SD) & $12.42 \pm 7.8$ & $11.86 \pm 10.1$ & 0.843 \\
\hline Reoperation, n (\%) & $1(8.3)$ & $7(26.9)$ & 0.318 \\
\hline Readmission, n (\%) & $0(0)$ & $4(15.4)$ & 1.000 \\
\hline
\end{tabular}

Data is shown as number (\%) or mean $\pm \mathrm{SD}$

*Indicates that $p<0.05$

BMI, body mass index; MIS, minimally invasive surgery; EBL, estimated blood loss; CD, clavien dindo; POPF, postoperative pancreatic fistula 
was found that the use of MIS for DP increased annually (Fig. 2; $p<0.001)$. Among the MIS patients, 36 (13.8\%) underwent robot-assisted surgery, and 140 (53.8\%) underwent laparoscopic surgery. Combined splenectomy was performed on 146 patients $(56.2 \%)$. The mean operative time was $235.4 \pm 90.9 \mathrm{~min}$. The mean length of hospital stay was $11.88 \pm 10.0 \mathrm{~d}$. Of the total number of patients, $12(4.6 \%)$ were categorized into Group 20K-High, and the other $248(95.4 \%)$ were categorized into Group 20K-Low.

\section{Postoperative WBC count after DP in Group 20K-High and Group 20K-Low}

The WBC count of Group 20K-High and Group 20KLow were significantly different on OP day, POD1, POD2, POD3, POD5, and POD7 (Fig. 3). There was no statistically significant difference between the groups, however, on pre-operative day $(7.19 \pm 2.57$ vs. $6.28 \pm 1.90$, $p=0.12)$ or day one of OPD $(8.75 \pm 3.26$ vs. $7.09 \pm 2.41$, $p=0.14$ ). Furthermore, there was no statistically significant difference in mean time from discharge day to first OPD between Group 20K-High and Group 20K-low (10.92 vs. 10.85 days, $p=0.97)$.

\section{Comparative analysis of perioperative outcomes between Group 20K-High and Group 20K-Low}

There was no statistically significant difference between Group 20K-High and Group 20K-Low with respect to gender, operation time, surgical approach, estimated blood loss, intraoperative transfusion, length of hospital

Table 3. Summary of severe complications following DP

\begin{tabular}{|c|c|c|c|c|c|c|c|c|c|}
\hline Complication (CD scale) & Age & BMI & Sex & Procedure & Op-name & EBL & WBC POD1 & LOH & OP time \\
\hline Obstruction (IV) & 71 & 25 & $\mathrm{~F}$ & Open & DPS & 100 & 13790 & 43 & 186 \\
\hline POPF (III) & 56 & 26 & M & $\begin{array}{l}\text { Laparoscopic } \\
\text { attempted }\end{array}$ & DPS & 1250 & 16240 & 20 & 252 \\
\hline POPF (III) & 37 & 26 & $\mathrm{M}$ & $\begin{array}{l}\text { Laparoscopic } \\
\text { attempted }\end{array}$ & DPS & 500 & 12600 & 23 & 319 \\
\hline Wound hematoma (III) & 38 & 20 & $\mathrm{~F}$ & Laparoscopic & DPS & 50 & 6440 & 12 & 158 \\
\hline Rebleeding (IV) & 36 & 21 & $\mathrm{~F}$ & Laparoscopic & SPDP & 0 & 10980 & 32 & 166 \\
\hline POPF (III) & 56 & 24 & M & Open & DPS & 200 & 12300 & 19 & 271 \\
\hline POPF (III) & 28 & 19 & $\mathrm{~F}$ & Laparoscopic & SPDP & 150 & 8310 & 28 & 141 \\
\hline POPF (III) & 33 & 23 & $\mathrm{M}$ & Open & DPS & 700 & 15430 & 130 & 155 \\
\hline POPF (III) & 48 & 21 & $\mathrm{~F}$ & Open & SPDP & 150 & 6110 & 18 & 112 \\
\hline POPF (III) & 53 & 23 & $\mathrm{~F}$ & Open & SPDP & 50 & 4720 & 13 & 120 \\
\hline Wound dehiscence (IV) & 67 & 23 & $\mathrm{M}$ & Laparoscopic & DPS & 250 & 16880 & 22 & 148 \\
\hline POPF (III) & 35 & 22 & $\mathrm{~F}$ & Robot & SPDP & 350 & 11470 & 6 & 301 \\
\hline Peritonitis (III) & 27 & 19 & $\mathrm{~F}$ & Laparoscopic & DPS & 250 & 22090 & 17 & 140 \\
\hline Pleural effusion (III) & 57 & 21 & $\mathrm{~F}$ & Laparoscopic & SPDP & 600 & 8800 & 11 & 205 \\
\hline Hematuria (III) & 60 & 23 & $\mathrm{~F}$ & $\begin{array}{l}\text { Laparoscopic } \\
\text { attempted }\end{array}$ & DPS & 800 & 17760 & 15 & 306 \\
\hline Fever (III) & 36 & 24 & M & Robot & SPDP & 700 & 13360 & 14 & 565 \\
\hline Fluid collection (III) & 29 & 27 & $\mathrm{~F}$ & $\begin{array}{l}\text { Laparoscopic } \\
\text { attempted }\end{array}$ & DPS & 300 & 16400 & 16 & 195 \\
\hline POPF (III) & 64 & 23 & $\mathrm{~F}$ & Open & DPS & 100 & 14350 & 33 & 172 \\
\hline Fluid collection (III) & 62 & 24 & $\mathrm{~F}$ & Open & DPS & 450 & 14520 & 28 & 239 \\
\hline POPF (III) & 32 & 24 & $\mathrm{~F}$ & Laparoscopic & SPDP & 400 & 9600 & 5 & 506 \\
\hline POPF (III) & 29 & 23 & $\mathrm{~F}$ & Laparoscopic & DPS & 300 & 11480 & 54 & 167 \\
\hline POPF (III) & 64 & 24 & $\mathrm{M}$ & Open & DPS & 1200 & 9090 & 22 & 180 \\
\hline Peritonitis (IV) & 27 & 20 & $\mathrm{~F}$ & Laparoscopic & DPS & 0 & 14570 & 11 & 180 \\
\hline POPF (III) & 54 & 22 & M & Open & SPDP & 500 & 11380 & 41 & 222 \\
\hline $\begin{array}{l}\text { Partial intestinal } \\
\text { obstruction (III) }\end{array}$ & 59 & 22 & $\mathrm{M}$ & Open & DPS & 0 & 9070 & 18 & 165 \\
\hline
\end{tabular}

CD scale, clavien dindo scale; BMI, body mass index; Op-name, operation name; EBL, estimated blood loss; WBC POD1, white blood cell(count) postoperative day 1; LOH, length of hospitalization; Op-time, operation time; DPS, distal pancreatectomy; SPDP, spleen preserving distal pancreatectomy; POPF, postoperative pancreatic fistula 
stays, reoperation, or readmission $(p>0.05)$. The overall complication rate was slightly higher in Group 20K-High with marginal significance, but the frequencies of clinically relevant major complications, including POPF, were similar between the two groups (Table 2). However, it was shown that age $(41.92 \pm 17.03$ years vs. $52.22 \pm 15.00$ years, $p=0.019)$, BMI $\left(20.48 \pm 4.08 \mathrm{~kg} / \mathrm{m}^{2}\right.$, vs. $23.22 \pm 3.06$ $\left.\mathrm{kg} / \mathrm{m}^{2}, p=0.01\right)$, and spleen-preserving rate ( $0 \%$ vs. $46 \%$, $p=0.002$ ) were significantly different between the two groups.

\section{Prediction of severe complications CD-III/IV following DP}

Table 3 shows the severe complications following DP. According to the Clavien-Dindo classification, 25 patients (9.6\%) had complications classified as grade III $(n=21)$ and IV $(n=4)$. There was pancreatic leakage in 13 patients $(52 \%)$, sustained abdominal pain with free air (peritonitis) in 2 patients $(8 \%)$, fluid collection in 2 patients $(8 \%)$, and wound complication in 2 patients (8\%). Since 2005, the number of cases of DP increased, but the rate of severe complications decreased annually ( $p<0.001$, Fig. 4), with no noted cases of severe complications in 2015 and 2016.

Univariate analysis demonstrated that surgical approach

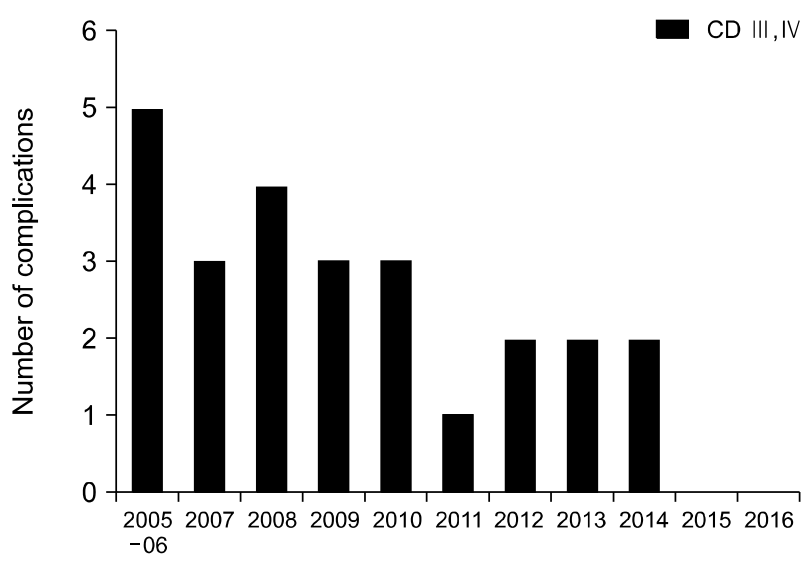

Fig. 4. Incidence of CD-III/IV complications after DP. There was annually decreasing trend $(p<0.001)$. CD, calvien-dindo; DP, distal pancreatectomy.

Table 4. Univariate predictors of major complications

\begin{tabular}{|c|c|c|c|}
\hline Variable & $\begin{array}{l}\text { Severe complication } \\
\qquad(\mathrm{N}=25)\end{array}$ & $\begin{array}{l}\text { Non-severe complication } \\
\qquad(\mathrm{N}=235)\end{array}$ & $p$-value \\
\hline Age, y, mean (SD) & $46.32 \pm 14.76$ & $52.32 \pm 15.18$ & 0.061 \\
\hline BMI, $\mathrm{kg} / \mathrm{m}^{2}$ (SD) & $22.82 \pm 2.12$ & $23.12 \pm 3.25$ & 0.571 \\
\hline Operative time, $\min (\mathrm{SD})$ & $222.80 \pm 110.35$ & $236.71 \pm 88.80$ & 0.468 \\
\hline WBC count on POD $1,10^{3} / \mu 1(\mathrm{SD})$ & $12.31 \pm 4.07$ & $12.23 \pm 4.15$ & 0.924 \\
\hline WBC $>20,000$ on POD1, n (\%) & & & 0.878 \\
\hline Yes & $1(4.0 \%)$ & $11(4.7 \%)$ & \\
\hline No & $24(96.0 \%)$ & $224(95.3 \%)$ & \\
\hline Gender, n $(\%)$ & & & 0.920 \\
\hline Male & $9(36.0 \%)$ & $87(37.0 \%)$ & \\
\hline Female & $16(64.0 \%)$ & $148(63.0 \%)$ & \\
\hline Spleen preserving, $\mathrm{n}(\%)$ & & & 0.406 \\
\hline Yes & $9(36.0 \%)$ & $105(44.7 \%)$ & \\
\hline No & $16(64.0 \%)$ & $130(55.3 \%)$ & \\
\hline Surgical approach, n (\%) & & & 0.008 \\
\hline MIS & $11(44.0 \%)$ & $165(70.2 \%)$ & \\
\hline Open & $14(56.0 \%)$ & $70(29.8 \%)$ & \\
\hline POPF, n (\%) & & & 0.044 \\
\hline Yes & $12(48.0 \%)$ & $67(28.5 \%)$ & \\
\hline No & $13(52.0 \%)$ & $168(71.5 \%)$ & \\
\hline Transfusion, ml (SD) & $74.00 \pm 216.56$ & $26.51 \pm 112.195$ & 0.290 \\
\hline Transfusion, n (\%) & & & 0.395 \\
\hline Yes & $3(12.0 \%)$ & $17(7.2 \%)$ & \\
\hline No & $22(88.0 \%)$ & $218(92.8 \%)$ & \\
\hline
\end{tabular}

Data is shown as number (\%) or mean $\pm \mathrm{SD}$

BMI, body mass index; WBC count on POD1, white blood cell count on postoperative day 1; MIS, minimally invasive surgery; POPF, postoperative pancreatic fistula 
Table 5. Binary logistic regression analysis of risk factors for severe complications $(\mathrm{n}=260)$

\begin{tabular}{lccc}
\hline \multirow{2}{*}{ Variable } & \multicolumn{2}{c}{ Severe complication } & \\
\cline { 2 - 3 } & OR & $95 \%$ CI & \\
\hline Age & 1.031 & $1.003-1.059$ & 0.032 \\
Open DP & 3.376 & $1.434-7.949$ & 0.005 \\
\hline
\end{tabular}

OR, adjusted odds ratio; 95\% CI, 95\% confidence interval; Open DP, open distal pancreatectomy

$(p=0.008)$ and POPF $(p=0.044)$ were associated with severe complications following DP (Table 4). Age was noted to have a marginal relationship with severe complications $(p=0.061)$. WBC count over $20 \mathrm{~K}$ on POD1 was not associated with severe complications after DP $(p=0.878)$. Subsequent multivariate analysis showed that age $(\mathrm{OR}=$ 1.031, [95\% CI: 1.003-1.059], $p=0.032)$ and surgical approach $(\mathrm{OR}=3.376,[95 \% \mathrm{CI}: 1.434-7.949], p=0.005)$ were associated with severe complications (Table 5).

\section{DISCUSSION}

POPF is the most serious complication in patients undergoing DP. POPF after DP has been reported in as many as $40 \%$ of patients, and this rate is higher than after pancreaticoduodenectomy. ${ }^{11-13}$ Objective data from perioperative laboratory tests may help surgeons predict complications after surgery; ${ }^{14,15}$ however, the prognostic significance of the WBC count in surgical patients with infection has not been thoroughly assessed. This study sought to predict the development of POPF or other severe complications after DP using the POD1 WBC count.

An elevation in WBC count can be used as a prognostic marker for infection or inflammation, but a variety of factors can lead to such elevation in otherwise asymptomatic individuals. Observational studies often fail to show an association between WBC extremes and infection in the immediate postoperative period in the surgical population. ${ }^{16,17}$ POPF after DP may lead to a systemic inflammatory response with leukocytosis and fever, resulting in a more complicated postoperative recovery and prolonged hospitalization. Thus, it is hypothesized that there is an association between POD1 leukocytosis and postoperative complications due to infection.

In this study, we enrolled 260 patients with benign and low-grade malignant tumors in the left side of the pan- creas and retrospectively compared the postoperative outcomes of two groups (Group 20K-High and Group 20K-Low) based on their WBC count on POD1 after DP. Twelve (4.6\%) of 260 patients in Group 20K-High associated with young age $(p=0.019)$, low BMI $(p=0.01)$, and splenectomy $(p=0.002)$. The high WBC count of Group 20K-High gradually decreased to near normal levels between POD7 and day 1 of OPD. A high WBC count immediately after the postoperative period was not associated with POPF or any severe complications. Multivariate analysis showed that age $(\mathrm{OR}=1.031)$ and open $\mathrm{DP}$ $(\mathrm{OR}=3.376)$ were independent factors capable of predicting severe complications following DP.

Since Velanovich ${ }^{18}$ reported in 2006 the first comparative study between laparoscopic DP (LDP) and open DP (ODP) and concluded that LDP produced surgical results equivalent to OPD, there have been several studies showing that MIS in DP is associated with decreased morbidity. ${ }^{19,20}$ Our retrospective results support that MIS in DP is associated with fewer severe complications. The potential association between severe complications and open DP was analyzed in this study by comparing the proportions of severe complications according to the laparoscopic approach used. Recent meta-analyses comparing LDP and ODP have shown the superiority of LDP in terms of intraoperative blood loss, patient recovery, and hospital stay. ${ }^{7,21-23}$ The first multicenter patient-blinded randomized control study of MIS in DP versus ODP (LEOPARD) reported MIS reduced the time to functional recovery compared with ODP. ${ }^{24}$

We found that a WBC count $>20 \mathrm{~K}$ cells $/ \mu$ l on POD1 after DP was a clinically uncommon phenomenon that occurred in only $12(4.6 \%)$ of 260 patients with DP. A postoperative WBC count $>20 \mathrm{~K}$ cells $/ \mu \mathrm{l}$ was found in the combined splenectomy group, and it returned to a normal range without clinically relevant severe complications. Thus, a WBC count $>20 \mathrm{~K}$ cells $/ \mu$ appears to be a physiologic change associated with splenectomy but not with severe complications after surgery. Previous reports ${ }^{25,26}$ demonstrated that DPS is associated with a statistically significant increase in postoperative $\mathrm{WBC}$ and platelet counts. Kehoe et al. ${ }^{27}$ also demonstrated that leukocytosis and thrombocytosis are common in upper abdominal surgery after a splenectomy. Additionally, investigators reported efforts to identify the mechanism underlying sple- 
nectomy-related leukocytosis. ${ }^{28}$ These studies suggested that the spleen exerts an inhibitory effect on bone marrow cell release and that after splenectomy, the circulation loses a factor that promotes cell apoptosis, thereby increasing the WBC count. Our results are in agreement with these findings, indicating that splenectomy is the most important factor for POD1 leukocytosis, as elevated WBC counts in the DPS group decrease to near-normal levels between POD7 and day 1 of OPD.

A major limitation of this study is the retrospective design and the limited number of patients. In addition, during the long study period, there may have been significant differences in postoperative techniques and perioperative management. Therefore, significant differences in severe complication rates between our early and late time periods were evident, as the standardized surgical techniques for DP changed during that time $(p<0.001)$. Nonetheless, it is interesting to note that the complication rate decreased annually. With increasing laparoscopic or robotic enhancement and the development of new surgical techniques, DP has become safer even during the course of this study. Currently, the MIS technique should be considered the operation of choice.

POD1 WBC counts $>20 \mathrm{~K}$ cells $/ \mu$ are not common following DP. POD1 WBC counts $>20 \mathrm{~K}$ cells/ $\mu$ l were related to a physiologic phenomenon resulting from combined splenectomy, not found to be a useful predictor of severe complications following DP. Instead, severe complications were found to be associated with age and open DP. Therefore, it may not necessary to imply clinical significance of the WBC count on POD1 after DP. It should be considered as a physiological change associated with the splenectomy. Surgeons are advised to apply laparoscopic or robotic surgery when performing DP in well selected patients with benign and low grade malignant tumor of the pancreas.

\section{REFERENCES}

1. Lillemoe KD, Kaushal S, Cameron JL, Sohn TA, Pitt HA, Yeo CJ. Distal pancreatectomy: indications and outcomes in 235 patients. Ann Surg 1999;229:693-698; discussion 698-700.

2. Kneuertz PJ, Patel SH, Chu CK, Fisher SB, Maithel SK, Sarmiento JM, et al. Laparoscopic distal pancreatectomy: trends and lessons learned through an 11-year experience. J Am Coll Surg 2012;215:167-176.

3. Stauffer JA, Coppola A, Mody K, Asbun HJ. Laparoscopic ver- sus open distal pancreatectomy for pancreatic adenocarcinoma. World J Surg 2016;40:1477-1484.

4. Fahy BN, Frey CF, Ho HS, Beckett L, Bold RJ. Morbidity, mortality, and technical factors of distal pancreatectomy. Am J Surg 2002; 183:237-241.

5. Kelly KJ, Greenblatt DY, Wan Y, Rettammel RJ, Winslow E, Cho CS, et al. Risk stratification for distal pancreatectomy utilizing ACS-NSQIP: preoperative factors predict morbidity and mortality. J Gastrointest Surg 2011;15:250-259, discussion 259-261.

6. Fox AM, Pitzul K, Bhojani F, Kaplan M, Moulton CA, Wei AC, et al. Comparison of outcomes and costs between laparoscopic distal pancreatectomy and open resection at a single center. Surg Endosc 2012;26:1220-1230.

7. Nakamura M, Wakabayashi G, Miyasaka Y, Tanaka M, Morikawa T, Unno M, et al.; Study Group of JHBPS, JSEPS. Multicenter comparative study of laparoscopic and open distal pancreatectomy using propensity score-matching. J Hepatobiliary Pancreat Sci 2015;22:731-736.

8. Haga Y, Beppu T, Doi K, Nozawa F, Mugita N, Ikei S, et al. Systemic inflammatory response syndrome and organ dysfunction following gastrointestinal surgery. Crit Care Med 1997;25: 1994-2000.

9. Dindo D, Demartines N, Clavien PA. Classification of surgical complications: a new proposal with evaluation in a cohort of 6336 patients and results of a survey. Ann Surg 2004;240:205213.

10. Bassi C, Dervenis C, Butturini G, Fingerhut A, Yeo C, Izbicki $\mathrm{J}$, et al.; International Study Group on Pancreatic Fistula Definition. Postoperative pancreatic fistula: an international study group (ISGPF) definition. Surgery 2005;138:8-13.

11. Sugimoto M, Gotohda N, Kato Y, Takahashi S, Kinoshita T, Shibasaki H, et al. Risk factor analysis and prevention of postoperative pancreatic fistula after distal pancreatectomy with stapler use. J Hepatobiliary Pancreat Sci 2013;20:538-544.

12. Lillemoe KD, Cameron JL, Kim MP, Campbell KA, Sauter PK, Coleman JA, et al. Does fibrin glue sealant decrease the rate of pancreatic fistula after pancreaticoduodenectomy? Results of a prospective randomized trial. J Gastrointest Surg 2004;8:766772; discussion 772-774.

13. Parikh P, Shiloach M, Cohen ME, Bilimoria KY, Ko CY, Hall BL, et al. Pancreatectomy risk calculator: an ACS-NSQIP resource. HPB (Oxford) 2010;12:488-497.

14. Da Silva M, Cleghorn MC, Elnahas A, Jackson TD, Okrainec A, Quereshy FA. Postoperative day one neutrophil-to-lymphocyte ratio as a predictor of 30-day outcomes in bariatric surgery patients. Surg Endosc 2017;31:2645-2650.

15. Giaccaglia V, Salvi PF, Cunsolo GV, Sparagna A, Antonelli MS, Nigri G, et al. Procalcitonin, as an early biomarker of colorectal anastomotic leak, facilitates enhanced recovery after surgery. J Crit Care 2014;29:528-532.

16. Kumar S, Mehta Y, Vats M, Chand R, Kapoor P, Trehan N. An observational study to know the association of leukocytosis and fever with infection in post cardiac surgery patients. Indian Heart J 2007;59:316-322.

17. Raymond DP, Crabtree TD, Pelletier SJ, Gleason TG, Banas LE, Patel S, et al. Extremes of white blood cell count do not independently predict outcome among surgical patients with infection. Am Surg 2000;66:1124-1130; discussion 1130-1131.

18. Velanovich V. Case-control comparison of laparoscopic versus open distal pancreatectomy. J Gastrointest Surg 2006;10:95-98.

19. Nigri GR, Rosman AS, Petrucciani N, Fancellu A, Pisano M, Zorcolo L, et al. Metaanalysis of trials comparing minimally invasive and open distal pancreatectomies. Surg Endosc 2011;25: 
1642-1651.

20. Venkat R, Edil BH, Schulick RD, Lidor AO, Makary MA, Wolfgang CL. Laparoscopic distal pancreatectomy is associated with significantly less overall morbidity compared to the open technique: a systematic review and meta-analysis. Ann Surg 2012;255:1048-1059.

21. Mehrabi A, Hafezi M, Arvin J, Esmaeilzadeh M, Garoussi C, Emami G, et al. A systematic review and meta-analysis of laparoscopic versus open distal pancreatectomy for benign and malignant lesions of the pancreas: it's time to randomize. Surgery 2015;157:45-55.

22. Ricci C, Casadei R, Taffurelli G, Toscano F, Pacilio CA, Bogoni $\mathrm{S}$, et al. Laparoscopic versus open distal pancreatectomy for ductal adenocarcinoma: a systematic review and meta-analysis. J Gastrointest Surg 2015;19:770-781.

23. Cesaretti M, Bifulco L, Costi R, Zarzavadjian Le Bian A. Pancreatic resection in the era of laparoscopy: State of Art. A systematic review. Int J Surg 2017;44:309-316.

24. de Rooij T, van Hilst J, van Santvoort H, Boerma D, van den
Boezem P, Daams F, et al.; Dutch Pancreatic Cancer Group. Minimally invasive versus open distal pancreatectomy (LEOPARD): a multicenter patient-blinded randomized controlled trial. Ann Surg 2019;269:2-9.

25. Tsiouris A, Cogan CM, Velanovich V. Distal pancreatectomy with or without splenectomy: comparison of postoperative outcomes and surrogates of splenic function. HPB (Oxford) 2011; 13:738-744

26. Tezuka K, Kimura W, Hirai I, Moriya T, Watanabe T, Yano M. Postoperative hematological changes after spleen-preserving distal pancreatectomy with preservation of the splenic artery and vein. Dig Surg 2012;29:157-164.

27. Kehoe SM, Eisenhauer EL, Chi DS. Upper abdominal surgical procedures: liver mobilization and diaphragm peritonectomy/resection, splenectomy, and distal pancreatectomy. Gynecol Oncol 2008;111(2 Suppl):S51-S55.

28. Djaldetti M, Bergman M, Salman H, Cohen AM, Fibach E, Bessler H. On the mechanism of post-splenectomy leukocytosis in mice. Eur J Clin Invest 2003;33:811-817. 